\title{
Gastro-esophageal reflux disease among type-2 diabetes mellitus patients in a rural area
}

\author{
Christopher S. Suwita, ${ }^{1}$ Benny, ${ }^{1}$ Daniel R. Mulyono, ${ }^{1}$ Selti Rosani, ${ }^{1}$ Yuni Astria, ${ }^{1}$ Felix F. Widjaja, ${ }^{2}$ \\ Ari F. Syam² \\ ${ }^{1}$ General Practitioner on Internship Program, Faculty of Medicine, Universitas Indonesia, Jakarta, Indonesia \\ 2 Department of Internal Medicine, Faculty of Medicine, Universitas Indonesia, Jakarta, Indonesia
}

\begin{abstract}
ABSTRAK
Latar belakang: Komplikasi diabetes melitus (DM) yang sering terabaikan adalah gastro-esophageal reflux disease (GERD), yang berkaitan dengan neuropati otonom dan gastropati diabetikum. Penelitian ini bertujuan mengetahui prevalensi GERD pada penderita DM melalui GERD-questionnaire (GERDQ), pengaruh diet, dan faktor-faktor lain yang berkaitan di daerah pedesaan.
\end{abstract}

Metode: Studi dilakukan menggunakan metode potonglintang di Puskesmas Pelaihari pada Agustus-September 2013. Pasien DM lama maupun baru berusia $\geq 18$ tahun yang dipilih secara konsekutif dengan kriteria eksklusi: kehamilan, sedang dalam pengobatan dengan proton-pump inhibitor, dan memiliki penyakit metabolik. Diagnosis DM ditegakkan berdasarkan kriteria American Diabetes Association (ADA), adapun diagnosis GERD ditegakkan bila nilai GERDQ berbahasa Indonesia $\geq 8$.

Hasil: Sebanyak 30 orang (29,7\%) dari 101 pasien DM mengalami GERD. Faktor diet pada pasien GERD adalah konsumsi pedas (90\%), makanan tinggi lemak (90\%), minuman iritatif (87\%), dan makanan iritatif (23\%). Hanya jenis kelamin perempuan yang berkaitan dengan GERD jika dibandingkan antara pasien DM dengan GERD vs non-GERD (87\% vs 68\%, $p=0,048)$. Adapun lama DM, (2 [0-13] vs 2 [0-19], $p=0,976)$, obesitas (37\% vs 38\%, $p=0,897)$, usia (53,2 $\pm 10,5$ vs $54,7 \pm 9,3, p$ $=0,481$ ), dan diabetes yang tidak terkontrol tidak berhubungan terhadap timbulnya GERD pada pasien DM.

Kesimpulan: Prevalensi GERD pada DM dalam penelitian ini cukup tinggi dan pada kelompok perempuan diperlukan skrining sedini mungkin.

\begin{abstract}
Background: One of the most neglected complications of diabetes mellitus (DM) is gastro-esophageal reflux disease (GERD) which arises from autonomic neuropathy and diabetic gastropathy related to the extent of DM. This study was done to find prevalence of GERD in DM patients with GERD-questionnaire (GERDQ), dietary factor proportion, and their association with other GERD risk factor in rural area.
\end{abstract}

Methods: This cross sectional study was conducted in Puskesmas Pelaihari from August to September 2013. Subjects with DM aged $\geq 18$ were selected consecutively from both newly and previously diagnosed patients with exclusion criteria: pregnancy, in proton-pump inhibitor therapy, and had other metabolic disease(s). DM was diagnosed with ADA criteria, while GERD was diagnosed in patients with score of $\geq 8$ of Indonesian GERDQ.

Results: There were 30 subjects (29.7\%) with GERD among 101 patients with DM and dietary factors found in GERD patients were spicy diet (90\%), high-fat food (90\%), irritative beverages (87\%), and irritative diet (23\%). Only female gender was associated with GERD vs non-GERD in DM patients $(87 \%$ vs $68 \%, p=0.048)$. Meanwhile, duration of DM (2 [0-13] vs 2 [0-19], p = 0.976), obesity (37\% vs $38 \%, p=0.897)$, age $(53.2 \pm 10.5$ vs $54.7 \pm 9.3, p=0.481)$, and uncontrolled diabetes ( $90 \%$ vs $94 \%, \mathrm{p}=0.421$ ) were not associated with the GERD among DM patients.

Conclusion: Prevalence of GERD in DM is somewhat high in this study. Female group with DM needs to be screened for GERD as early as possible.

Keywords: diabetes mellitus, gastro-esophageal reflux disease, GERD-questionnaire, rural area

pISSN: 0853-1773 • eISSN: 2252-8083 • http://dx.doi.org/10.13181/mji.v24i1.1164 • Med J Indones. 2015;24:43-9

- Received 30 Nov $2014 \cdot$ Accepted 20 Feb 2015

Correspondence author: Christopher S. Suwita, dr.tophersuwita@gmail.com

Copyright @ 2015 Authors. This is an open access article distributed under the terms of the Creative Commons Attribution-NonCommercialShareAlike 4.0 International License (http://creativecommons.org/licenses/by-nc-sa/4.0/), which permits unrestricted non-commercial use, distribution, and reproduction in any medium, provided the original author and source are properly cited. 
Diabetes mellitus (DM) is a chronic hyperglycemic state secondary to deficiency in insulin secretion and/or insulin activity. ${ }^{1}$ Being the fourth country with most diabetes, Indonesia had 8.4 million people with DM in 2000.2,3

Gastro-esophageal reflux disease (GERD), known as one of many diabetes related complications, ${ }^{4}$ is a symptomatic gastrointestinal disorder caused by gastric acid reflux. ${ }^{5}$ In Indonesia, there was an increase in GERD prevalence from $6 \%$ in 1997 to $26 \%$ in $2002^{6}$ due to the drastic changes in community behaviour such as more drugs consumption, unhealthy diet, sedentary lifestyle, and smoking. ${ }^{7}$

In daily practice, while GERD is often established as a non-severe case, it can be a serious disease with very high rate of medical and non-medical complications including Barrett's esophagus, malignancy, socio economic burden, and declined quality of life. ${ }^{8}$ In the current standard, ambulatory esophageal $\mathrm{pH}$ monitoring remains unsatisfying as a gold standard so that the patients' medical history with/without endoscopic examination still plays a major role in the diagnosis. ${ }^{9}$ GERD-questionnaire (GERDQ) includes reference questions comprised of typical and atypical symptoms of the disease for GERD-suspected patients and it is a simple diagnostic tool to be used in primary health care..$^{10,11}$

Closely related to the duration of DM, higher incidence of GERD in DM is attributable to autonomic neuropathy and diabetic gastropathy. ${ }^{4}$ As the consequences, there are more frequent findings of impaired lower esophageal sphincter (LES) tone and gastric dysmotility in DM than non-DM population. ${ }^{4,12-15}$ Studies conducted in various countries have shown that GERD was a frequent complication in approximately $23-29 \%$ of DM patients and reached up to half of total diabetes cases in New Jersey, United States. ${ }^{15-20}$

Another complexity of DM in the case of GERD is that DM will give poor prognostic effect to the latter since: (1) DM will reduce the effectiveness of acid-suppression therapy, which is the mainstay therapy of GERD ${ }^{21}$ and; (2) DM increases the occurrence of Barrett's esophagus and esophageal cancer. ${ }^{22}$

The presence of GERD in DM patients is often missed. For that reason, we aimed to find the prevalence of GERD by GERDQ in DM patients and some of its associated factors at Puskesmas (pusat kesehatan masyarakat, primary health care center) as the basis of comprehensive treatment of DM, especially in a rural area.

\section{METHODS}

This study used cross-sectional design and was conducted from August to October 2013 in Puskesmas Pelaihari of South Kalimantan. This primary health care centre covers approximately 57,408 citizens of which 460 people $(0.6-1.0 \%)$ have DM. ${ }^{2}$

All patients who had been newly or previously diagnosed with DM were included in this study using consecutive sampling. The inclusion criterion for this study was diabetic patients aged $\geq 18$ years who visited Puskesmas and/or its services. The exclusion criteria were pregnancy, in treatment of proton-pump inhibitor (PPI), and/or had other metabolic disorders such as hyperthyroidism. New DM patients were diagnosed using American Diabetes Association (ADA) criteria: fasting plasma glucose (FPG) $\geq$ $126 \mathrm{mg} / \mathrm{dL}$ or random plasma glucose $\geq 200 \mathrm{mg} /$ $\mathrm{dL}$ in the conjunction of characteristic complaints such as polydipsia, polyphagia, polyuria, and weight loss without apparent cause; if there was no such complaint, then the aforementioned tests had to show at least two abnormal results before the diagnosis was established. ${ }^{1}$

Subjects who met all the criteria were asked to complete questionnaires that included subjects' characteristics, GERDQ and habits/lifestyle associated with GERD. Subjects who were not able to read/write filled the questionnaire by assisted questionnaire-filling method. Subjects' characteristics were age, sex, DM duration, height/ weight, body mass index (BMI), blood pressure (systolic and diastolic), control of plasma glucose level, and diabetes drugs consumed. Plasma glucose level was assumed controlled when at the last examination FPG $\geq 100 \mathrm{mg} / \mathrm{dL}$ or random plasma glucose $\geq 200 \mathrm{mg} / \mathrm{dL}^{1}{ }^{1}$ Risk factors asked in this study were obesity, female gender, smoking (Brinkman index), irritative foods, spicy foods, high-fatty foods, and irritative beverages intake per week, and other drugs taken. Obesity was classified according to Asia Pacific criteria, ${ }^{23}$ 
then we grouped obese I and II to obese and the other as non-obese.

GERD was diagnosed with validated GERDQ in Indonesian language. ${ }^{24}$ Each subject with GERDQ score $\geq 8,{ }^{10}$ was assumed having GERD and subsequently was given information about the disease and empirical acid-suppression therapy and/or referred for endoscopic examination in larger health centers. ${ }^{25}$ Subject's then-approval to undergo treatment/examination was not evaluated in this study.

All subjects were given informed consent in writings after being provided a description of the study to be conducted. This protocol was conducted in accordance with the principles in the Declaration of Helsinki and had been approved by the Head of Puskesmas Pelaihari. All data were kept confidential.

Tabulation and processing of data were made by SPSS Statistics for Windows version 13.0. For categoric variable, Chi-square was used and Fisher test was used as alternative. For numeric variable, T-test was used when the variable was normally distributed, and Mann-Whitney was used as alternative.

\section{RESULTS}

From 101 patients, 30 (29.7\%) had GERD. Female (74\%) was more predominant than male and almost all of the subjects (93\%) had poor control of their plasma glucose level. In addition, DM patients were found having obesity and hypertension with proportion of $38 \%$ and $43 \%$, respectively. The characteristics of this study subjects were described in table 1 . In this study we found that only female was associated with GERD in DM patients $(\mathrm{p}=0.048)$. Meanwhile, duration of diabetes $(\mathrm{p}=0.976)$, obesity $(\mathrm{p}=0.897)$, age $(\mathrm{p}$ $=0.481)$, and uncontrolled diabetes $(p=0.421)$ were not significantly different in GERD and nonGERD among DM patients. In DM patients who was smoking, the median (range) of Brinkman index was 13.5 (6-780) in GERD and 80 (1-1584) in non-GERD.

Table 1 showed that $71 \%$ of subjects were currently taking anti-hyperglycemic agents and more than half of them used metformin and glibenclamide as combination therapy. Subjects' targeted plasma glucose level was not achieved optimally, though; FPG median was 156 (111-408) $\mathrm{mg} / \mathrm{dL}$ and random plasma glucose mean was 270

Table 1. Subjects characteristics

\begin{tabular}{|c|c|c|c|}
\hline Variables & $\begin{array}{c}\text { Total } \\
\mathrm{n}=101\end{array}$ & $\begin{array}{l}\text { GERD } \\
\mathrm{n}=30\end{array}$ & $\begin{array}{c}\text { non-GERD } \\
n=71\end{array}$ \\
\hline Age, mean (SD) years & $54.2(9.7)$ & $53.2(10.5)$ & $54.7(9.3)$ \\
\hline BMI, mean (SD) kg/m² & $24.07(4.32)$ & $23.96(4.01)$ & $24.12(4.48)$ \\
\hline$\geq 25, \mathrm{n}(\%)$ & $38(38)$ & $11(37)$ & $27(38)$ \\
\hline$<25, \mathrm{n}(\%)$ & $63(62)$ & $19(63)$ & $44(62)$ \\
\hline Male gender, $\mathrm{n}(\%)$ & 27 (27) & $4(13)$ & $23(32)$ \\
\hline Diabetes duration, median (range) years & $2(0-19)$ & $2(0-13)$ & $2(0-19)$ \\
\hline \multicolumn{4}{|l|}{ Blood pressure (BP) mmHg } \\
\hline Systolic BP, median (range) & $140(90-220)$ & $130(90-220)$ & $140(100-210)$ \\
\hline Diastolic BP, median (range) & $80(60-110)$ & $80(60-110)$ & $90(60-110)$ \\
\hline Uncontrolled plasma glucose level, n (\%) & $94(93)$ & $27(90)$ & $67(94)$ \\
\hline Smoking, n (\%) & $19(19)$ & $6(20)$ & $13(18)$ \\
\hline \multicolumn{4}{|l|}{ Subjects using anti-diabetic agents, n (\%) } \\
\hline No anti-diabetic & $29(29)$ & $9(30)$ & $20(28)$ \\
\hline Glibenclamide & $18(18)$ & $5(17)$ & $13(18)$ \\
\hline Metformin & $11(11)$ & $2(7)$ & $9(13)$ \\
\hline Metformin + glibenclamide & $41(40)$ & $13(43)$ & $28(39)$ \\
\hline Others (gliclazide, glimepiride, insulin) & $2(2)$ & $1(3)$ & $1(1)$ \\
\hline
\end{tabular}


$\pm 91 \mathrm{mg} / \mathrm{dL}$. Moreover, regardless of their antidiabetic medication, as many as 59 subjects (58\%) consumed other drugs with anti-hypertensive on the top of the list, followed by antacids, statins, and non-steroidal anti-inflammatory drugs (NSAID).

Table 2 showed that heartburn and epigastric pain were, in a mere glance, the most common GERD symptoms found. However, based on the intensity, heartburn and nausea were the most severe symptoms in $43 \%$ and $54 \%$ of subjects of whom had these complaints for four until seven 4-7 days/week.

The proportion of various dietary factors found in this study classified to GERD/non-GERD group might be observed in table 3 . The consumption of high-fat food such as food rich in coconut milk and/or saturated fat, irritative beverages such as coffee/tea, and spicy food were the most common risk factors found in the study subjects; these diets were even consumed every day.

\section{DISCUSSION}

The prevalence of GERD among DM patients in this study (30\%) was higher than that within the normal population in Indonesia $(26 \%)^{6}$ and in

Table 2. GERD symptoms in 30 patients with GERD from 101 DM patients

\begin{tabular}{ll}
\hline Symptoms & $\mathrm{n}$ \\
\hline Heartburn & 28 \\
Regurgitation & 26 \\
Epigastric pain & 28 \\
Nausea & 26 \\
Nocturnal regurgitation & 17 \\
Drugs taken for relieving symptoms & 19 \\
\hline
\end{tabular}

Table 3. Dietary factors in DM patients with GERD and nonGERD

\begin{tabular}{lcccc}
\hline \multirow{2}{*}{ Risk factors } & \multicolumn{2}{c}{ GERD } & \multicolumn{2}{c}{ non-GERD } \\
\cline { 2 - 5 } & $\mathrm{n}(\%)$ & Frequency* & $\mathrm{n}(\%)$ & Frequency* \\
\hline High-fat food & $27(90)$ & $5(0-15)$ & $66(93)$ & $4(0-21)$ \\
Irritative beverage & $26(87)$ & $4(0-28)$ & $63(89)$ & $7(0-40)$ \\
Spicy food & $27(90)$ & $7(0-21)$ & $60(85)$ & $7(0-21)$ \\
Irritative diet & $7(23)$ & $0(0-7)$ & $19(27)$ & $0(0-14)$ \\
\hline
\end{tabular}

*median (range) servings per week other Eastern countries such as Japan (20\%), ${ }^{25,26}$ Taiwan $(25 \%),{ }^{27}$ and Turk $(19.1 \%)^{28}$ all of which used questionnaire method as we did. This was relevant with others' findings which showed GERD was more prevalent in DM patients than non-DM patients. ${ }^{4,13,14}$ Nonetheless, GERD in this study was less prevalent than GERD in DM patients in United States $(40.8 \%$ in DM population vs $18.1-27.8 \%$ in its general population). ${ }^{15,29}$ It might be caused by higher mean BMI in that study $\left(32 \pm 7.2 \mathrm{~kg} / \mathrm{m}^{2}\right)^{15}$ than the BMI in our study $\left(24.07 \pm 4.32 \mathrm{~kg} / \mathrm{m}^{2}\right)$, resulting in worse GERD symptoms attributable to the co-morbidity. ${ }^{13,20}$

Still, prevalence of the disease in our study was higher than that of other similar questionnaire studies in Japan $(23-29 \%)^{16,18}$ and Korea (23.1\%). ${ }^{19}$ Our result even topped prevalence in Spain (28\%) which also used ambulatory 24-hour esophageal pH-monitoring, ${ }^{17}$ so that its result should have been higher consequently due to inclusion of asymptomatic GERD in DM patients.

High GERD prevalence in this study may be caused by poor control of plasma glucose level (94\%) and female predominance $(73 \%)$. Symptomatic GERD is commonly found in poor glycemic control patients. ${ }^{13}$ In addition, many studies showed that while complicated GERD (with alarm signs) tends to be more common in men, uncomplicated GERD is predominantly affecting women, both within DM and non-DM population. ${ }^{18,28-33}$ This study also showed that female was associated with GERD in DM patients $(p=0.048)$. Moreover, the number of female was higher because hours of service in our primary health care coincided with daily work hours so there would be more non-working patients visiting, for example housewives,

It was interesting that while longer duration of DM (8 vs 11 years) was closely related to the prevalence of GERD, ${ }^{13}$ but DM duration in this study was not associated with GERD ( $p=0.976)$. It was caused by the relative short duration of diabetes with median of 2 years. In line with our practice experience where the study took place, this phenomenon might be due to subjects' limited knowledge to the importance of routine medical checkups and glucose control so that their diabetes would: (1) diagnosed late so it would appear like a newly-diagnosed DM, which in reality was not, and/or; (2) rapidly progressed to an extent where neuropathy and gastropathy started to be found. 
Additionally, it should be pointed out that both of the age of the patients and control of blood glucose had no significance to the prevalence of GERD ( $p$ $=0.481$ and 0.421 ), owing to the majority of the subjects was in middle-age (40-60 year old, mean 54.2 y.o) and most of them ( $\geq 90 \%$ of both group) lacked proper glycemic control.

Similar to non-DM population, the most frequent GERD symptoms found in this study were heartburn and epigastric pain. BIt was hypothesized due to: (1) increased secretion of $\mathrm{H}^{+}$in the stomach secondary to hyperglycemia; (2) delayed esophagus and gastric emptying, and; (3) increased relaxation of the lower LES accompanied by its decreased tone. Although they were also experienced by normal population, a person with DM had much higher fault in the last two factors, making him/her more vulnerable to GERD typical symptoms. ${ }^{34,35}$ However, as the metabolic system worsened, there would have been deterioration of autonomic and peripheral nervous system (diabetic neuropathy) accompanied by disruption of esophageal and gastric peristalsis (diabetic gastropathy), resulting in atypical GERD symptoms. ${ }^{4,30,36}$ Hence, the most severe symptoms found in this study were epigastric pain and nausea.

This study had also found that most common risk factors routinely consumed by the subjects were high-fat diet, spicy food, and irritative beverages. The specific type of diet was in accordance with the typical Asian diet, i.e. rich in coconut milk, with lots of spices (especially that posed a strong flavor like spicy), high of saturated fatty acids, and usually accompanied by coffee/tea. ${ }^{37}$ In this study, the mentioned risk factors proportion between GERD/non-GERD group were found to have no difference. It was confirmed by several studies that had revealed only obesity and supine position after meal worsened GERD symptoms. ${ }^{38,39}$

Nevertheless, our study showed that obesity was not associated with GERD ( $p=0.897)$. Beside the constraint in the total number of subjects, it might be because we did not assess all risk factors of GERD, and since GERD has multifactorial etiology a comorbid alone may not be an isolated cause. ${ }^{7}$

By proportion of $20 \%$ of smoking in GERD patients and $18 \%$ in non-GERD patients, there was no difference between smoking group. This result is consistent with another study claiming currently there had been no scientific evidence on the effect of cigarette/tobacco in progressivity of GERD. $^{39}$

Among drugs taken by the subjects, majority of them were included in the class of antihyperglycemic, anti-hypertensive, antihyperlipidemic, and nonsteroidal anti-inflammatory drugs (NSAIDs). Those drugs, along with other sofrequently taken agents, were listed by Yamamichi, et $\mathrm{al}^{33}$ in their study about lifestyle plus medication factors on GERD symptoms described by frequency scale for the symptoms of GERD FSSG score. The study found that despite anti-hyperglycemic, anti-hypertensive, anti-hyperlipidemic, and NSAID influenced GERD symptoms, significant improvement was only obtained by (diabetic) patients taking anti-hyperglycemic; on the contrary, NSAIDs would worsen the symptoms. ${ }^{33}$

Based on the annual report of Puskesmas Pelaihari in 2012 (unpublished data), patients seeking medical help for upper gastrointestinal complaints reached $34 \%$ of total visits. However, in daily practices GERD was still a disease that had been neglected; most of GERD diagnoses were made after we had used GERDQ as the study proceeded. In DM patients who had atypical symptoms, it could be estimated that the morbidities coming from failure to find GERD would be much higher because they were diagnosed with other diseases.

Therefore, the making of early diagnosis and effective management of GERD in DM plays very important role due to contradictory clinical evidences and atypical, or even asymptomatic, clinical symptoms. Ideally, the diagnosis of GERD is carried out by: (1) clinical history of gastrointestinal system such as heartburn and regurgitation after excluding the involvement of cardiac origin; (2) symptoms improvement after empirical acid-suppression therapy for 4-6 weeks; (3) ambulatory esophageal pH-monitoring, and; (4) endoscopy. ${ }^{36,40}$

In rural areas, such ideal mentioned above is often difficult; there are limitations to health facilities, human resources, transportation methods, and other socioeconomic circumstances. Moreover, the referral system in such areas, none of which considering those circumstances, can only be carried out step by step from a smaller district 
hospital to a larger provincial hospital. In addition, pH-monitoring also had its own limitation; GERD symptoms in DM patients often resulted from autonomic nervous dysfunction with no difference in 24-hour $\mathrm{pH}^{41}$ For these reasons, in term of practicality, history-taking using GERDQ should be a primary diagnosis method in limited health facilities. ${ }^{10}$

This study certainly came with some limitations. First, many of the subjects were illiterate and/or did not comprehend the intent of the questions; as a result, there was a subjective bias in filling out the questionnaire with assisted questionnaire method. However, the use of GERDQ in this study was indeed effective and efficient because it was not lengthy but still described the most common symptoms of the patient. As with the other limitation, this study did not include all risk factors for GERD and did not analyze their association with GERD.

The advantages of this study were its originality; there has been no study in Indonesia which studied GERD in DM population, used questionnaire as a diagnostic tool, and was carried out in rural areas.

\section{Acknowledgment}

We sincerely express our gratitude to all the staff of Puskesmas Pelaihari, South Kalimantan and $\mathrm{Hj}$. Isna Farida, MD as the head of the facility for their participation and support in this study. We also thank all of our patients/subjects for their eagerness and cooperation, which made this study possible.

\section{Conflicts of Interest}

The authors affirm no conflict of interest in this study.

\section{REFERENCES}

1. American Diabetes Association. Diagnosis and classification of diabetes mellitus. Diabetes Care. 2010;33(Suppl1):S62-9.

2. Badan Penelitian dan Pembangunan Kesehatan. Riset kesehatan dasar (Riskesdas) 2007. Jakarta: Departemen Kesehatan Republik Indonesia; 2008. Indonesian.

3. Wild S, Roglic G, Green A, Sicree R, King H. Global prevalence of diabetes: estimates for the year 2000 and projections for 2030. Diabetes Care. 2004;27(5):1047-53.

4. Kinekawa F, Kubo F, Matsuda K, Inoue H, Kuriyama S. Gastroesophageal reflux disease in diabetic patients. Nihon Rinsho. 2004;62(8):1546-52. Japanese.
5. Cao Y, Yan X, Ma XQ, Wang R, Johansson S, Wallander $M A$, et al. Validation of a survey methodology for gastroesophageal reflux disease in China. BMC Gastroenterology. 2008;8:37.

6. Aulia C. Prevalence of non-erosive reflux disease in Pondok Indah Hospital: a preliminary study. Acta Med Indones. 2005;37(2):79-81.

7. Lelosutan SAR, Manan C, Nur BM. The role of gastric acidity and lower esophageal sphincter tone on esophagitis among dyspeptic patients. Indones J Gastroenterol Hepatol Dig Endosc. 2001;2(3):6-11.

8. Ang TL, Fock KM, Ng TM, Teo EK, Chua TS, Tan J. A comparison of the clinical, demographic and psychiatric profiles among patients with erosive and non-erosive reflux disease in a multi-ethnic Asian country. World J Gastroenterol. 2005;11(23):3558-61.

9. Shaw MJ, Talley NJ, Beebe TJ, Rockwood T, Carlsson $\mathrm{R}$, Adlis $\mathrm{S}$, et al. Initial validation of a diagnostic questionnaire for gastroesophageal reflux disease. Am J Gastroenterol. 2001;96(1):52-7.

10. Jonasson C, Moum B, Bang C, Andersen KR, Hatlebakk JG. Randomised clinical trial: a comparison between a GerdQ-based algorithm and an endoscopy-based approach for the diagnosis and initial treatment of GERD. Aliment Pharmacol Ther. 2012;35(11):1290300.

11. Andrijani PK, Manan C, Simadibrata M, Siregar P. Specific subjective symptoms for gastroesophageal reflux disease in ulcer like dyspepsia. Indones J Gastroenterol Hepatol Dig Endosc. 2004;5(1):7-14.

12. Frokjaer JB, Andersen SD, Ejskjaer N, Funch-Jensen P, Drewes AM, Gregersen H. Impaired contractility and remodeling of the upper gastrointestinal tract in diabetes mellitus type-1. World J Gastroenterol. 2007;13(36):4881-90.

13. Kase H, Hattori Y, Sato N, Banba N, Kasai K. Symptoms of gastroesophageal reflux in diabetes patients. Diabetes Res Clin Pract. 2008;79(2):e6-7.

14. Kinekawa F, Kubo F, Matsuda K, Kobayashi M, Furuta Y, Fujita Y, et al. Esophageal function worsens with long duration of diabetes. J Gastroenterol 2008;43(5):338-44.

15. Wang $X$, Pitchumoni CS, Chandrarana K, Shah N. Increased prevalence of symptoms of gastroesophageal reflux diseases in type 2 diabetics with neuropathy. World J Gastroenterol. 2008;14(5):709-12.

16. Hirata A, Kishida $K$, Nakatsuji H, Inoue $K$, HiugeShimizu A, Funahashi T, et al. High prevalence of gastroesophageal reflux symptoms in type 2 diabetics with hypoadiponectinemia and metabolic syndrome. Nutr Metab (Lond). 2012;9(1):4.

17. Lluch I, Ascaso JF, Mora F, Minguez M, Peña A, Hernandez A, et al. Gastroesophageal reflux in diabetes mellitus. Am J Gastroenterol. 1999;94(4):919-24.

18. Horikawa A, Ishii-Nozawa $R$, Ohguro M, Takagi $S$, Ohtuji M, Yamada M, et al. Prevalence of GORD (gastrooesophageal reflux disease) in type 2 diabetes and a comparison of clinical profiles between diabetic patients with and without GORD. Diabet Med. 2009;26(3):228-33.

19. Lee SD, Keum B, Chun HJ, Bak YT. Gastroesophageal reflux disease in type II diabetes mellitus with or without peripheral neuropathy. J Neurogastroenterol Motil. 2011;17(3):274-8. 
20. Maev IV, Iurenev GL, Kakhramanova DA. [Peculiarities of gastroesophageal reflux disease in patients with type 2 diabetes mellitus]. Klin Med (Mosk). 2012;90(9):53-6. Russian.

21. Hershcovici T, Jha LK, Gadam R, Cui H, Gerson L, Thomson $\mathrm{S}$, et al. The relationship between type 2 diabetes mellitus and failure to proton pump inhibitor treatment in gastroesophageal reflux disease. J Clin Gastroenterol. 2012;46(8):662-8.

22. Iyer PG, Borah BJ, Heien HC, Das A, Cooper GS, Chak A. Association of Barrett's esophagus with type II Diabetes Mellitus: results from a large populationbased case-control study. Clin Gastroenterol Hepatol. 2013;11(9):1108-14.

23. World Health Organization. The Asia-Pacific perspective: redefining obesity and its treatment. Sydney: Health Communication Australia Pty Ltd; 2000.

24. Simadibrata M, Rani A, Adi P, Djumhana A, Abdullah M. The gastro-esophageal reflux disease questionnaire using Indonesian language: a language validation survey. Med J Indones. 2011;20(2):125-30.

25. Fujiwara Y, Arakawa T. Epidemiology and clinical characteristics of GERD in the Japanese population. J Gastroenterol. 2009;44(6):518-34.

26. Yamagishi H, Koike T, Ohara S, Kobayashi S, Ariizumi $\mathrm{K}$, Abe $\mathrm{Y}$, et al. Prevalence of gastroesophageal reflux symptoms in a large unselected general population in Japan. World J Gastroenterol. 2008;14(9):1358-64.

27. Hung LJ, Hsu PI, Yang CY, Wang EM, Lai KH. Prevalence of gastroesophageal reflux disease in a general population in Taiwan. J Gastroenterol Hepatol. 2011;26(7):1164-8.

28. Mungan Z. Prevalence and demographic determinants of gastroesophageal reflux disease (GERD) in the Turkish general population: a population-based cross-sectional study. Turk J Gastroenterol. 2012;23(4):323-32.

29. El-Serag HB, Sweet S, Winchester CC, Dent J. Update on the epidemiology of gastro-oesophageal reflux disease: a systematic review. Gut. 2014;63(6):871-80

30. Sonnenberg A, El-Serag HB. Clinical epidemiology and natural history of gastroesophageal reflux disease. Yale J Biol Med. 1999;72(2-3):81-92.

31. Nilsson M, Johnsen R, Ye W, Hveem K, Lagergren J. Prevalence of gastro-oesophageal reflux symptoms and the influence of age and sex. Scand J Gastroenterol. 2004;39(11):1040-5

32. Lin M, Gerson LB, Lascar R, Davila M, Triadafilopoulos G. Features of gastroesophageal reflux disease in women Am J Gastroenterol. 2004;99(8):1442-7.

33. Yamamichi N, Mochizuki S, Asada-Hirayama I, MikamiMatsuda R, Shimamoto T, Konno-Shimizu M, et al. Lifestyle factors affecting gastroesophageal reflux disease symptoms: a cross-sectional study of healthy 19864 adults using FSSG scores. BMC Medicine. 2012;10:45.

34. Promberger R, Lenglinger J, Riedl O, Seebacher G, Eilenberg WH, Ott J, et al. Gastro-oesophageal reflux disease in type 2 diabetics: symptom load and patophysiologic aspects - a retro-pro study. BMC Gastroenterology. 2013;13:132.

35. Promberger $R$, Gadenstätter $M$, Ciovica $R$, Schwab G, Neumayer G. Gastrooesophageal reflux disease in diabetic patients: a systematic review. Eur Surg. 2007;39(6):340-54.

36. Katz PO, Gerson LB, Vela MF. Guidelines for the diagnosis and management of gastroesophageal reflux disease. Am J Gastroenterol. 2013;108(3):308-28.

37. Ishige N. The dietary culture of Asia [Internet]. New York: AsiaSociety. 2008 Sept- [cited 2013 Oct 12] Available from: http://asiasociety.org/blog/asia/ dietary-culture-asia.

38. El-Serag HB, Satia JA, Rabeneck L. Dietary intake and the risk of gastro-oesophageal reflux disease: a cross sectional study in volunteers. 2005;54(1):11-7.

39. Kaltenbach T, Crockett S, Gerson LB. Are lifestyle measures effective in patients with gastroesophageal reflux disease? An evidence-based approach. Arch Intern Med. 2006;166(9):965-71.

40. Talley NJ, Silverstein MD, Agréus L, Nyrén O, Sonnenberg A, Holtmann G. AGA technical review: evaluation of dyspepsia. American Gastroenterological n. Gastroenterology. 1998;114(3):582-95.

41. Jackson AL, Rashed H, Cardoso S, Wong F, Werkman R, Thompson J, etal. Assessment of gastric electrical activity and autonomic function among diabetic and nondiabetic patients with symptoms of gastroesophageal reflux. Dig Dis Sci. 2000;45(9):1727-30. 